Supporting information for

\title{
Closing the gap: Preparation and characterization of the first half-open and open manganocene complexes
}

\author{
Matthias Reiners, Dirk Baabe, Matthias Freytag, Peter G. Jones and Marc D. Walter*a
}

Institut für Anorganische und Analytische Chemie, Technische Universität Braunschweig, Hagenring 30, 38106

Braunschweig, Germany

E-mail: mwalter@tu-bs.de

Table of Content:

1. Crystallographic details on complexes 2-5 S2

2. Crystallographic details om $\left[\left(\mathrm{C}_{5} \mathrm{H}_{5}\right)_{2} \mathrm{Mn}\right] \quad \mathrm{S} 3$

3. Degradation study on complex $4 \quad$ S5

4. Field-dependent magnetic studies on complexes 2-5 S6

5. Evaluation of the axial zero-field splitting parameter D on compounds $\mathbf{2}$ and $4 \quad$ S8

6. UV/vis spectra of compounds $\mathbf{2 - 5} \quad$ S9

7. Computational details $\quad$ S9

$\begin{array}{ll}7.1 \text { Energies of optimized structures } & \text { S9 }\end{array}$

7.2 (Biorthogonalized) Kohn Sham orbitals for compounds 2-5 S10

$\begin{array}{ll}\text { 7.3 Computed molecular structures and spin states for complex } 5 & \text { S12 }\end{array}$

$\begin{array}{ll}\text { 7.4 Spin distribution and NBO charges for complex } 5 & \text { S12 }\end{array}$

8. References $\quad$ S13 


\section{Crystallographic details on complexes 2-5}

Table S1. Crystallographic data for compounds 2-5

\begin{tabular}{|c|c|c|c|c|}
\hline Compound reference & 2 & 3 & 4 & 5 \\
\hline Chemical formula & $\mathrm{C}_{30} \mathrm{H}_{52} \mathrm{Mn}$ & $\mathrm{C}_{30} \mathrm{H}_{50} \mathrm{Mn}$ & $\mathrm{C}_{26} \mathrm{H}_{46} \mathrm{Mn}$ & $\mathrm{C}_{36} \mathrm{H}_{56} \mathrm{Mn}_{3}$ \\
\hline Formula Mass & 467.67 & 465.65 & 413.58 & 653.64 \\
\hline Crystal system & monoclinic & monoclinic & monoclinic & monoclinic \\
\hline $\mathrm{a} / \AA$ & $15.3055(7)$ & $10.1685(3)$ & $21.2311(13)$ & $14.3756(2)$ \\
\hline $\mathrm{b} / \AA$ & $9.7880(4)$ & $27.0688(6)$ & $12.0793(6)$ & $9.14393(10)$ \\
\hline $\mathrm{c} / \AA$ & $19.7121(9)$ & $20.3896(5)$ & $20.8194(10)$ & $26.3730(3)$ \\
\hline$\alpha /^{\circ}$ & 90.00 & 90.00 & 90.00 & 90.00 \\
\hline$\beta /^{\circ}$ & $108.810(5)$ & $92.203(3)$ & $106.741(6)$ & $102.611(2)$ \\
\hline$\gamma /{ }^{\circ}$ & 90.00 & 90.00 & 90.00 & 90.00 \\
\hline Unit cell volume $/ \AA^{3}$ & $2795.4(2)$ & $5608.1(2)$ & $5113.0(5)$ & $3383.09(7)$ \\
\hline Temperature/K & $100(2)$ & $150(2)$ & $130(2)$ & $130(2)$ \\
\hline Space group & $\mathrm{P} 2{ }_{1} / \mathrm{n}$ & $\mathrm{P} 2{ }_{1} / \mathrm{c}$ & $\mathrm{C} 2 / \mathrm{c}$ & $\mathrm{P} 2{ }_{1} / \mathrm{n}$ \\
\hline No. of formula units per unit cell, Z & 4 & 8 & 8 & 4 \\
\hline Radiation type & Mo K $\alpha$ & $\mathrm{Cu} \mathrm{K \alpha}$ & $\mathrm{Cu} \mathrm{K \alpha}$ & $\mathrm{Cu} \mathrm{K \alpha}$ \\
\hline Absorption coefficient, $\mu / \mathrm{mm}^{-1}$ & 0.486 & 3.899 & 4.219 & 9.113 \\
\hline No. of reflections measured & 55766 & 275679 & 46338 & 67561 \\
\hline No. of independent reflections & 8297 & 11661 & 5302 & 7065 \\
\hline $\mathrm{R}_{\mathrm{int}}$ & 0.0688 & 0.0897 & 0.0551 & 0.0700 \\
\hline Final $\mathrm{R}_{1}$ values $(\mathrm{I}>2 \sigma(\mathrm{I}))$ & 0.0419 & 0.0599 & 0.0363 & 0.0362 \\
\hline Final $w R\left(F^{2}\right)$ values $(I>2 \sigma(I))$ & 0.0827 & 0.1188 & 0.0914 & 0.0885 \\
\hline Final $\mathrm{R}_{1}$ values (all data) & 0.0710 & 0.0649 & 0.0432 & 0.0385 \\
\hline Final $w R\left(\mathrm{~F}^{2}\right)$ values (all data) & 0.0946 & 0.1210 & 0.0969 & 0.0900 \\
\hline Goodness of fit on $\mathrm{F}^{2}$ & 1.029 & 1.195 & 1.063 & 1.113 \\
\hline
\end{tabular}




\section{Crystallographic details on $\left[\left(\mathrm{C}_{5} \mathrm{H}_{5}\right)_{2} \mathrm{Mn}\right]$}

Table S2. Crystal data and structure refinement.

\begin{tabular}{|c|c|c|}
\hline Identification code & \multicolumn{2}{|l|}{$\left[\left(\mathrm{C}_{5} \mathrm{H}_{5}\right)_{2} \mathrm{Mn}\right]$} \\
\hline Empirical formula & \multicolumn{2}{|l|}{$\mathrm{C}_{10} \mathrm{H}_{10} \mathrm{Mn}$} \\
\hline Formula weight & \multicolumn{2}{|l|}{185.12} \\
\hline Temperature & \multicolumn{2}{|l|}{$100(2) \mathrm{K}$} \\
\hline Wavelength & \multicolumn{2}{|l|}{$0.71073 \AA$} \\
\hline Crystal system & \multicolumn{2}{|l|}{ Monoclinic } \\
\hline Space group & \multicolumn{2}{|l|}{$\mathrm{P} 2{ }_{1} / \mathrm{c}$} \\
\hline \multirow[t]{3}{*}{ Unit cell dimensions } & $a=14.9991(6) \AA$ & $\alpha=90^{\circ}$ \\
\hline & $\mathrm{b}=9.8929(4) \AA$ & $\beta=111.814(5)^{\circ}$ \\
\hline & $\mathrm{c}=11.4925(5) \AA$ & $\gamma=90^{\circ}$ \\
\hline Volume & \multicolumn{2}{|l|}{$1583.19(11) \AA^{3}$} \\
\hline $\mathrm{Z}$ & \multicolumn{2}{|l|}{8} \\
\hline Density (calculated) & \multicolumn{2}{|l|}{$1.553 \mathrm{Mg} / \mathrm{m}^{3}$} \\
\hline Absorption coefficient & \multicolumn{2}{|l|}{$1.587 \mathrm{~mm}^{-1}$} \\
\hline $\mathrm{F}(000)$ & \multicolumn{2}{|l|}{760} \\
\hline Crystal size & \multicolumn{2}{|c|}{$0.22 \times 0.20 \times 0.15 \mathrm{~mm}^{3}$} \\
\hline Theta range for data collection & \multicolumn{2}{|c|}{2.53 to $30.87^{\circ}$} \\
\hline Index ranges & \multicolumn{2}{|c|}{$-21<=\mathrm{h}<=21,-14<=\mathrm{k}<=13,-16<=1<=16$} \\
\hline Reflections collected & \multicolumn{2}{|c|}{42078} \\
\hline Independent reflections & \multicolumn{2}{|c|}{$4745[\mathrm{R}(\mathrm{int})=0.0437]$} \\
\hline Completeness to theta $=30.00^{\circ}$ & \multicolumn{2}{|c|}{$98.9 \%$} \\
\hline Absorption correction & \multicolumn{2}{|c|}{ Semi-empirical from equivalents } \\
\hline Max. and min. transmission & \multicolumn{2}{|c|}{1.00000 and 0.96335} \\
\hline Refinement method & \multicolumn{2}{|c|}{ Full-matrix least-squares on $\mathrm{F}^{2}$} \\
\hline Data / restraints / parameters & \multicolumn{2}{|c|}{$4745 / 42 / 212$} \\
\hline Goodness-of-fit on $\mathrm{F}^{2}$ & \multicolumn{2}{|c|}{1.062} \\
\hline Final $R$ indices $[\mathrm{I}>2 \operatorname{sigma}(\mathrm{I})]$ & \multicolumn{2}{|c|}{$\mathrm{R} 1=0.0343, \mathrm{wR} 2=0.0696$} \\
\hline $\mathrm{R}$ indices (all data) & \multicolumn{2}{|c|}{$\mathrm{R} 1=0.0452, \mathrm{wR} 2=0.0749$} \\
\hline Largest diff. peak and hole & \multicolumn{2}{|c|}{0.502 and -0.393 e. $\AA^{-3}$} \\
\hline
\end{tabular}

Refinement details: The structure was refined as a pseudo-merohedral twin with twin matrix $\left[\begin{array}{lllllll}1 & 0 & 1 / & 0 & -1 & 0 & \text { / } \\ 0 & 0 & -1\end{array}\right]$ (the orthorhombic pseudo-cell is generated by the matrix [0 0 -1/ $-20-1 / 010]$ and has cell constants $a=11.492, b$ $=27.853, c=9.893 \AA, \alpha=\beta=90, \gamma=89.3^{\circ}$ ). The relative volume of the smaller domain refined to $0.055(1)$. The $\eta^{5}$ coordinated ring at Mn was disordered and was refined on two positions with relative occupancy $0.825 / 0.175(8)$. There were slight indications of a similar disorder at $\mathrm{Mn}^{\prime}$, but this might also be a manifestation of bonding electron density in the ring.

Discussion of the structure: The structure of $\mathrm{MnCp}_{2}$ was investigated some decades ago, at room temperature, by Coppens ${ }^{[1]}$ and Bünder \& Weiss ${ }^{[2]}$. The former investigation established the same cell as reported here and also commented on the pseudo-merohedral twinning via an orthorhombic cell, but did not establish the complete structure. The latter study showed that the structure consists of chains of alternating manganese atoms and Cp rings with one "extra" Cp peripherally attached to each manganese; however, it used a halved orthorhombic cell and some atoms therefore showed very high and irregular $U$ values. Our study confirms the polymeric nature of the structure (Fig. S1).

The structure is unusual in displaying twinning, pseudosymmetry (via a pseudo-translation of $\mathbf{c} / 2$, from which however some atom pairs deviate by up to $0.3 \AA$ ) and disorder. Although we are reasonably confident that the first two problems have been adequately dealt with, dimensions of disordered groups should always be interpreted with caution. 


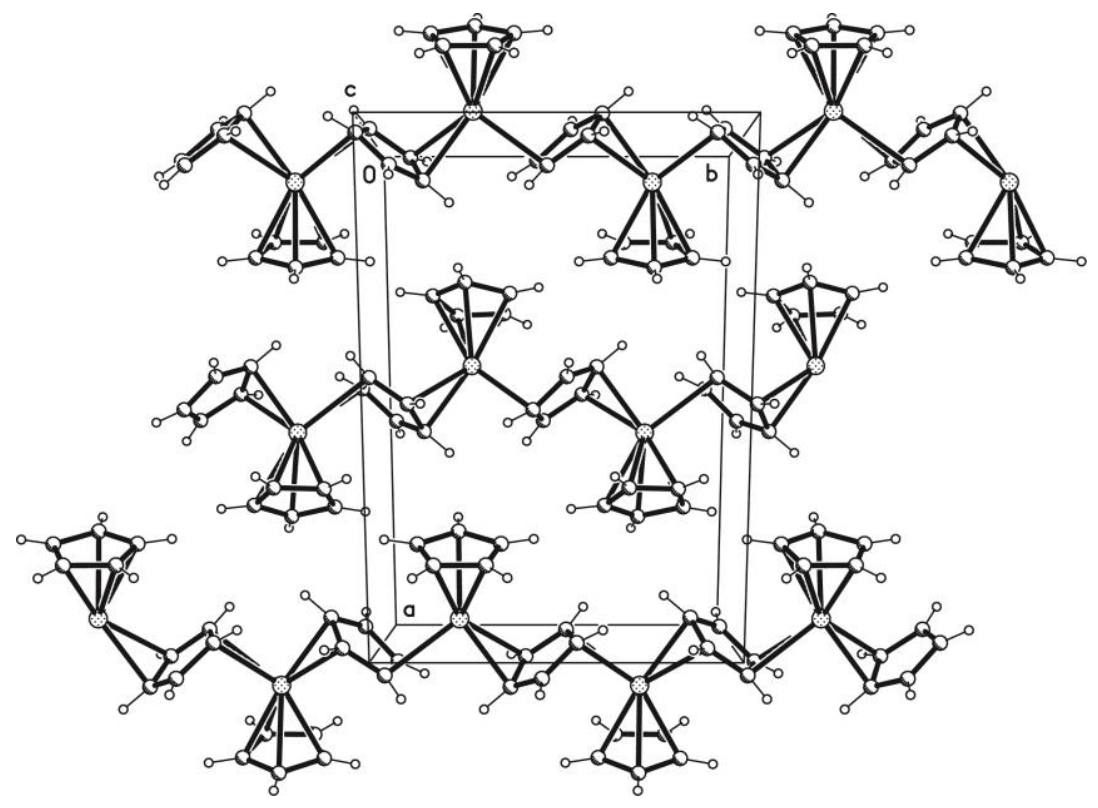

Figure S1. Packing diagram for $\left[\left(\mathrm{C}_{5} \mathrm{H}_{5}\right)_{2} \mathrm{Mn}\right]$.
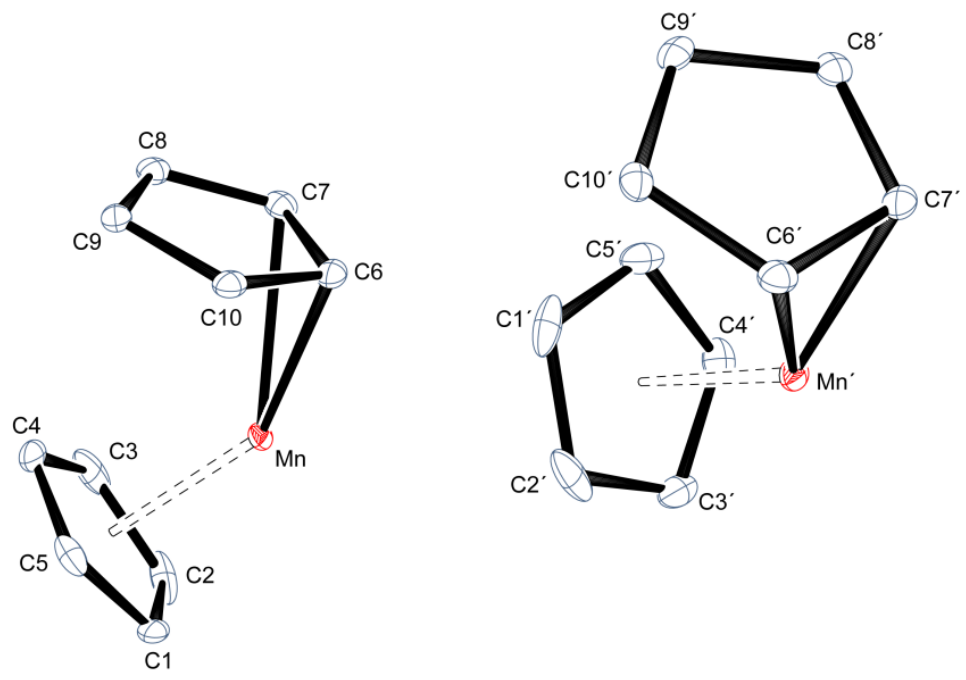

Figure S2. Asymmetric unit of $\left[\left(\mathrm{C}_{5} \mathrm{H}_{5}\right)_{2} \mathrm{Mn}\right]$ with thermal displacement parameters drawn at $30 \%$ probability. Hydrogen atoms were omitted for clarity. Selected bond distances ( $)$ : Mn-C1 2.370(2), Mn-C2 2.385(3), Mn-C3 2.416(3), Mn-C4 2.450(3), Mn-C5 2.404(2), Mn-C6 2.3382(18), C8-Mn\#2 2.5981(19), C9-Mn\#2 2.4262(18), Mn'C1' 2.399(2), Mn'-C2' 2.400(2), Mn'-C3' 2.4128(19), Mn'-C4' 2.403(2), Mn'-C5' 2.396(2), Mn'-C6' 2.5192(19), Mn'C7' 2.3531(17), Mn'-C9'\#3 2.4025(17), Mn'-C10'\#3 2.5576(18). Symmetry transformations used to generate equivalent atoms: $\# 2-\mathrm{x}+1, \mathrm{y}-1 / 2,-\mathrm{z}+1 / 2, \# 3-\mathrm{x}+2, \mathrm{y}+1 / 2,-\mathrm{z}+1 / 2$ 


\section{Degradation study on complex 4}

In order to probe the thermally driven degradation of complex $\mathbf{4}$ in more detail, the decrease in $\mu_{\text {eff }}$ was recorded as a function of time at constant temperatures $\mathrm{T}=300$ and $350 \mathrm{~K}$, respectively (Figure S3). While there is no significant sample degradation at $\mathrm{T}=300 \mathrm{~K}$ for $c a .200 \mathrm{~min}$, the magnetic moment decreases rapidly when the sample is heated to $\mathrm{T}=350 \mathrm{~K}$, and the value of $\mu_{\text {eff }}$ decreases from $5.56 \mu_{\mathrm{B}}$ to $2.23 \mu_{\mathrm{B}}$ within approx. $20 \mathrm{~min}$. This corresponds to a first-order rate constant $\mathrm{k}(350 \mathrm{~K})=0.11(2) \mathrm{min}^{-1}\left(\Delta \mathrm{G}^{\ddagger}(350 \mathrm{~K})=25.0(2) \mathrm{kcal} / \mathrm{mol}\right)$. It is interesting to note that the magnetic moment stays constant at this temperature for $c a .150 \mathrm{~min}$ before further degradation is observed, which, however, occurs much more slowly $\left(\mathrm{k}(350 \mathrm{~K})=0.0025(1) \mathrm{min}^{-1} ; \Delta \mathrm{G}^{\ddagger}(350 \mathrm{~K})=27.6(1) \mathrm{kcal} / \mathrm{mol}\right)$. Nevertheless, both processes result in a degradation product $4^{*}$, which shows a magnetic moment of $1.81 \mu_{\mathrm{B}}$ at $\mathrm{T}=300 \mathrm{~K}$ (see Figures S3 and S4). Unfortunately, we cannot provide additional information on the identity of $4 *$ at this time. However, differences in the size of the crystallites used for the magnetic susceptibility measurement may potentially be invoked as an explanation for the different decomposition rates. Further investigations of this aspect are currently in progress.

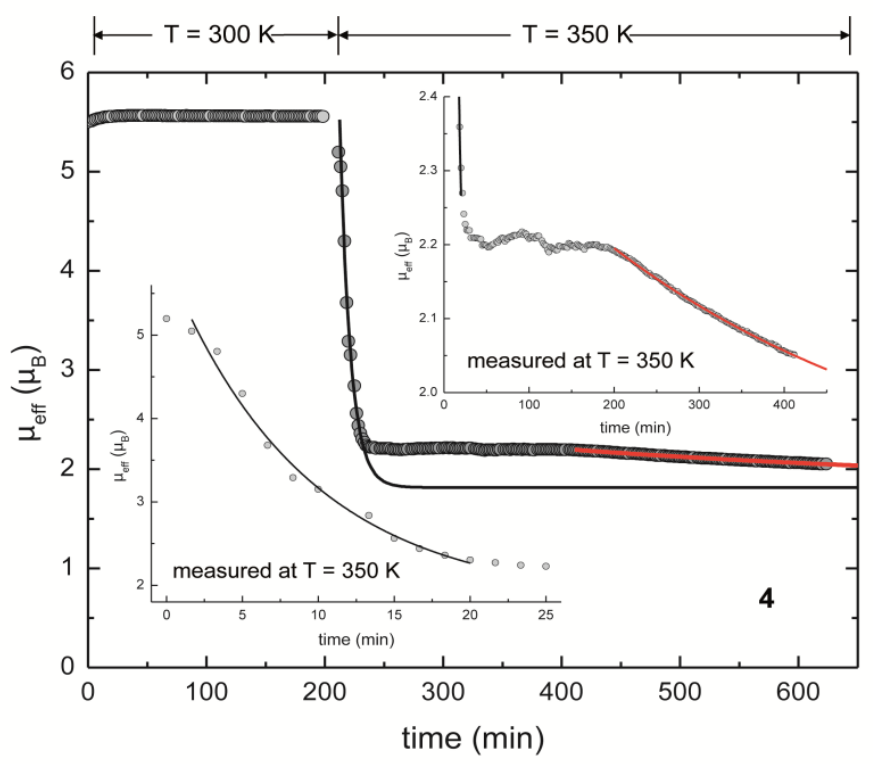

Figure S3. $\mu_{\text {eff }}$ vs. time plots of complex 4 recorded at $\mathrm{T}=300$ and $350 \mathrm{~K}$ with an external applied magnetic field of $1000 \mathrm{G}$. The adaptation of an exponential decay law on the time-dependent evolution of $\mu_{\text {eff }}$ is shown in the insets (see text). 


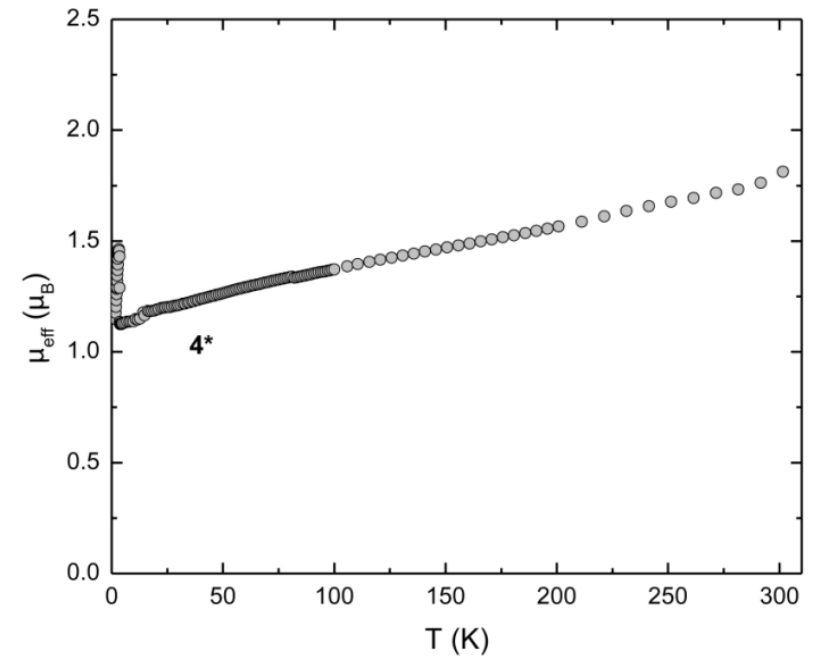

Figure S4. $\mu_{\text {eff }}$ vs. T plot of the thermally degraded complex $4 *$ recorded between $\mathrm{T}=2.6$ and $300 \mathrm{~K}$ with an external applied magnetic field of $1000 \mathrm{G}$.

\section{Field-dependent magnetic studies on complexes 2-5}

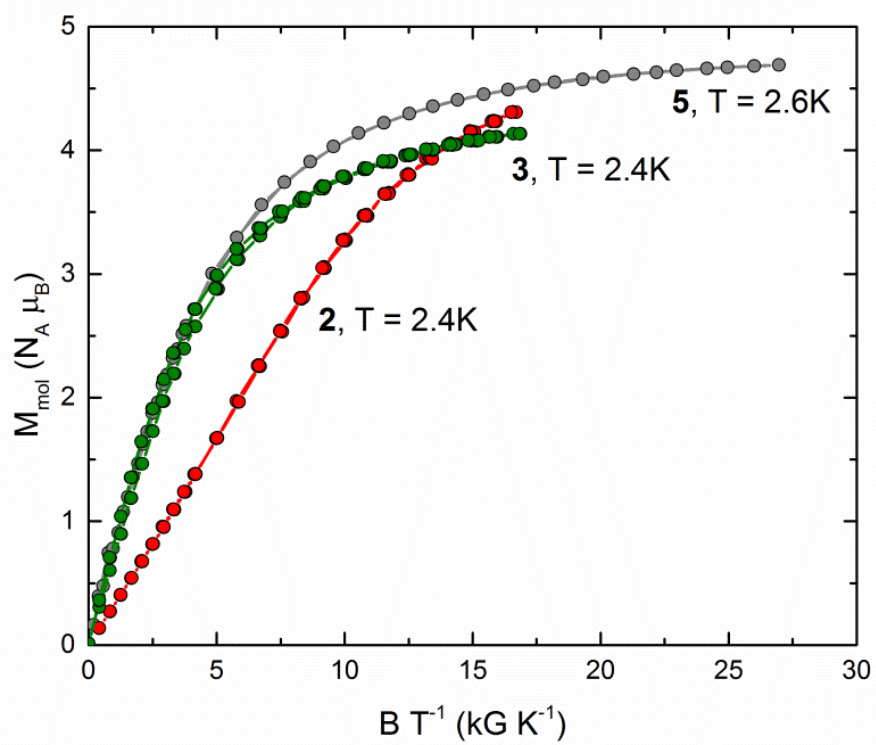

Figure S5. Molar magnetization $\left(\mathrm{M}_{\mathrm{mol}}\right)$ vs. $\mathrm{BT}^{-1}$ plot of complexes $\mathbf{2 , 3}$ and $\mathbf{5}$ recorded at $\mathrm{T}=2.4$ to $2.6 \mathrm{~K}$ with external applied magnetic fields between $500 \mathrm{G}$ and $70 \mathrm{kG}$. 


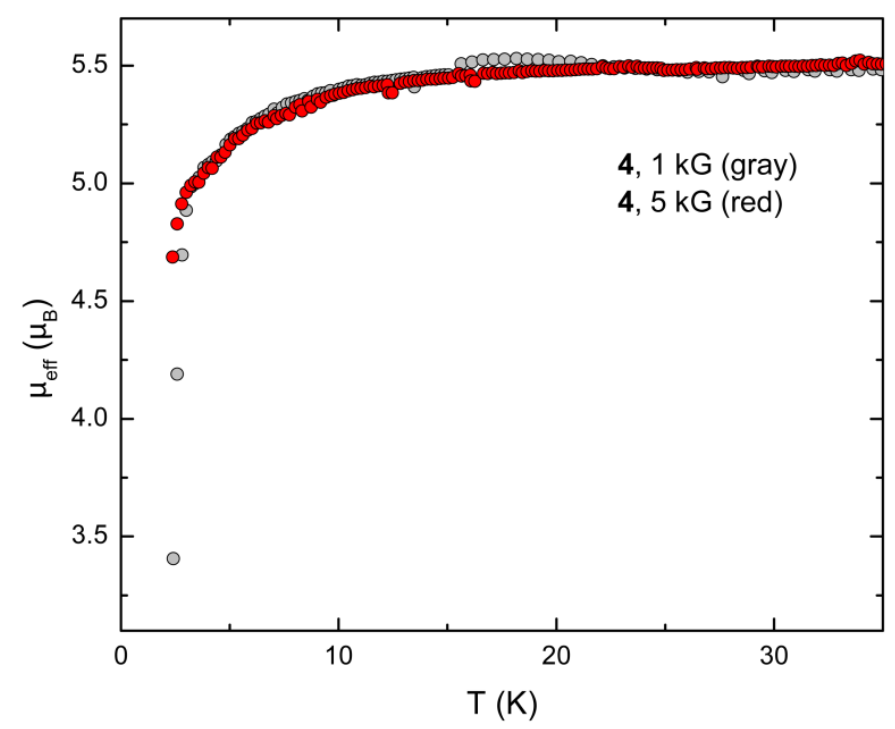

Figure S6. $\mu_{\text {eff }}$ vs. $T$ plots of complex 4 recorded between $T=2.6$ and $300 \mathrm{~K}$ with external applied magnetic fields of 1000 and $5000 \mathrm{G}$, respectively.

From the magnetic field-dependence of the molar magnetization of compounds $\mathbf{2 , 3}$ and $\mathbf{5}$ (Figure S5) it can clearly be deduced that all of these compounds are still within the Curie regime at $1000 \mathrm{G}$ and temperatures of $\mathrm{T}=2.4$ to 2.6 K. Furthermore, the tracking $\mu_{\text {eff }}$ vs. T plots of complex 4 recorded with external applied magnetic fields of 1000 and $5000 \mathrm{G}$ (Figure S6) confirm that the Curie law approximation is also valid for this compound at low temperatures and with an external applied magnetic field of $1000 \mathrm{G}$. Hence, the decrease in the effective magnetic moment observed for compounds $\mathbf{2}$ and $\mathbf{4}$ at low temperatures must be ascribed to the presence of zero-field splitting (vide infra). 


\section{Evaluation of the axial zero-field splitting parameter D on compounds 2 and 4}

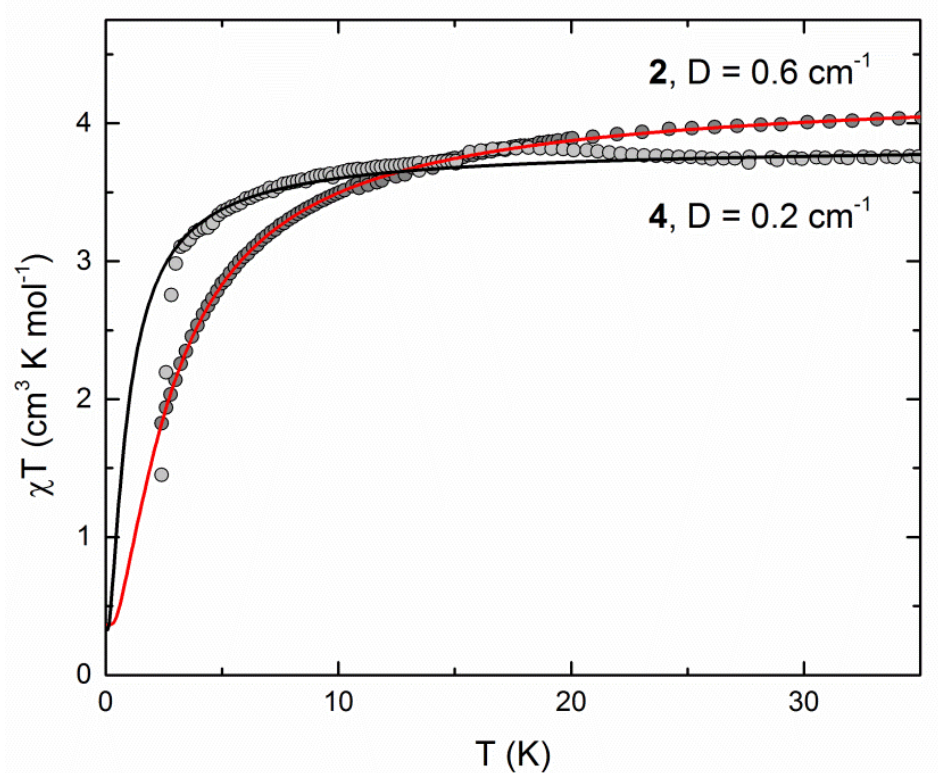

Figure S7. $\chi \mathrm{T}$ vs. $\mathrm{T}$ plot for complexes 2 and 4 recorded between $\mathrm{T}=2.6$ and $40 \mathrm{~K}$ with an external applied magnetic field of $1000 \mathrm{G}$. The solid lines represent the result of the fitting routine with the model described in the text.

The $\chi \mathrm{T}$ vs. $\mathrm{T}$ curves of compounds $\mathbf{2}$ and $\mathbf{4}$ were analyzed on the basis of a simplified spin Hamiltonian for $\mathrm{S}=5 / 2$ systems with negligible rhombic zero-field splitting $(\mathrm{ZFS})$ parameter $(\mathrm{E} / \mathrm{D}=0)$ by use of the Van Vleck equation:

$$
\chi T=\left(2 N_{A} \mu_{0} g^{2} \mu_{B}^{2} / k_{B}\right) \frac{\frac{25}{4} \exp \left(-\frac{40}{12} \frac{D}{k_{B}}\right)+\frac{9}{4} \exp \left(\frac{8}{12} \frac{D}{k_{B}}\right)+\frac{1}{4} \exp \left(\frac{32}{12} \frac{D}{k_{B}}\right)}{\exp \left(-\frac{40}{12} \frac{D}{k_{B}}\right)+\exp \left(\frac{8}{12} \frac{D}{k_{B}}\right)+\exp \left(\frac{32}{12} \frac{D}{k_{B}}\right)}+\chi_{D} T
$$

whereby D denotes the axial component of the ZFS tensor and $\chi_{\mathrm{D}}$ considers a marginal (phenomenological) diamagnetic correction $\left(\chi_{\mathrm{D}}=-1.69 \times 10^{-4}\right.$ and $-2.75 \times 10^{-4} \mathrm{~cm}^{3} \mathrm{~mol}^{-1}$ for complex $\mathbf{2}$ and $\mathbf{4}$, respectively) to account for the experimental data. The $\mathrm{D}$ values obtained are $\mathrm{D}=0.90 \mathrm{~K}\left(0.6 \mathrm{~cm}^{-1}\right)$ and $0.29 \mathrm{~K}\left(0.2 \mathrm{~cm}^{-1}\right)$ for complex 2 and $\mathbf{4}$, respectively.

The agreement between the experimental and simulated data is excellent for complex $\mathbf{2}$, whereas the low-temperature regime of complex 4 cannot satisfactorily be adopted. This suggests that the assumption of $E / D=0$ is not valid for this derivative, but a closer evaluation of this aspect would require high-field EPR measurements. 


\section{UV/vis spectra of compounds 2-5}

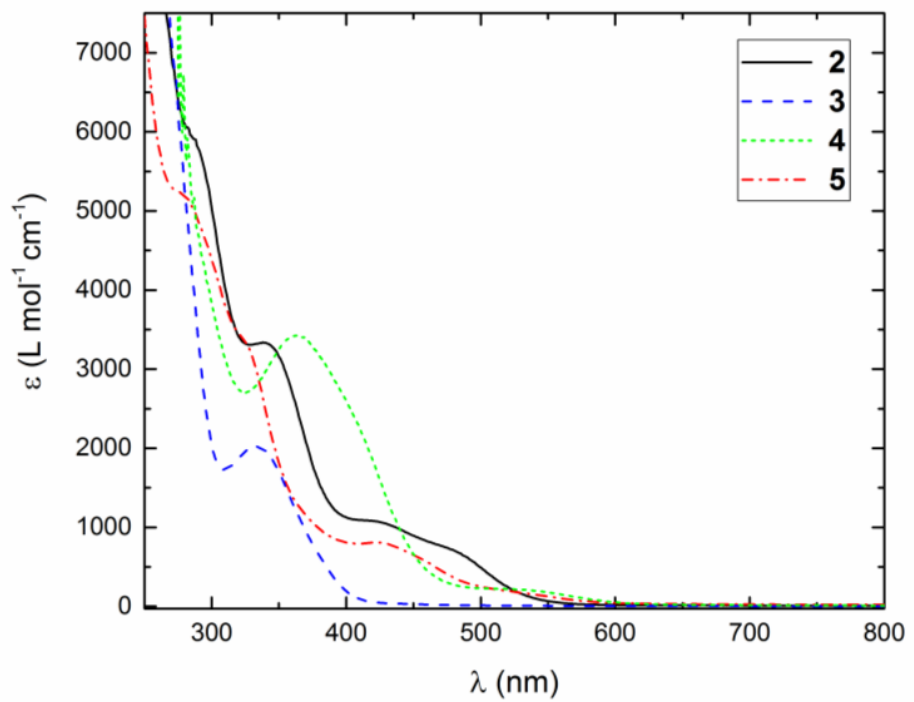

Figure S8. UV/vis spectra of compounds 2-5 (recorded in pentane at $25^{\circ} \mathrm{C}$ ).

\section{Computational details}

\subsection{Energies of optimized structures}

All computations were performed using the DFT functional method B97D and B3LYP as implemented in the Gaussian09 program. ${ }^{[2]}$ The all-electron triple- $\zeta$ basis set $\left(6-311 \mathrm{G}^{* *}\right)^{[3]}$ was applied for all elements $(\mathrm{Mn}, \mathrm{C}$ and $\mathrm{H})$.

Table S3. Energies of the optimized structures

\begin{tabular}{|c|c|c|c|}
\hline Compound & 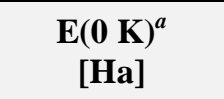 & $\begin{array}{c}\mathbf{H}(298 \mathrm{~K})^{b} \\
{\left[\begin{array}{l}b a \\
0\end{array}\right.}\end{array}$ & $\begin{array}{c}\mathbf{G}(298 \mathrm{~K})^{b} \\
{[\mathrm{Ha}]}\end{array}$ \\
\hline \multicolumn{4}{|c|}{ B3LYP: } \\
\hline$\left.\left[\left(\eta^{5}-\mathrm{Cp} "\right) \mathrm{Mn}(\mathrm{Pdl})^{\prime}\right)\right](2, \mathrm{~S}=1 / 2)$ & -2325.019731 & -2324.981185 & -2325.082815 \\
\hline$\left[\left(\eta^{5}-\mathrm{Cp} "\right) \mathrm{Mn}\left(\mathrm{Pdl}^{\prime}\right)\right](2, \mathrm{~S}=5 / 2)$ & -2325.045550 & -2325.005526 & -2325.115558 \\
\hline$\left[\left(\eta^{5}-C p^{\prime \prime}\right) \operatorname{Mn}\left(\eta^{5}-C p^{\prime}\right)\right](3, S=1 / 2)$ & -2323.860590 & -2323.822861 & -2323.923894 \\
\hline$\left[\left(\eta^{5}-\mathrm{Cp} "\right) \mathrm{Mn}\left(\eta^{5}-\mathrm{Cp} \mathrm{p}^{\prime}\right)\right](\mathbf{3}, \mathrm{S}=5 / 2)$ & -2323.894512 & -2323.854949 & -2323.964360 \\
\hline$\left[\left(\mathrm{Pdl}^{\prime}\right)_{2} \mathrm{Mn}\right](\mathbf{4}, \mathrm{S}=1 / 2)$ & -2169.024990 & -2168.989000 & -2169.093319 \\
\hline$\left[\left(\mathrm{Pdl}^{\prime}\right)_{2} \mathrm{Mn}\right](4, \mathrm{~S}=3 / 2)$ & -2169.001392 & -2168.965672 & -2169.066437 \\
\hline$\left[\left(\mathrm{Pdl}^{\prime}\right)_{2} \mathrm{Mn}\right](4, \mathrm{~S}=5 / 2)$ & -2169.024848 & -2168.988957 & -2169.092521 \\
\hline
\end{tabular}




$$
\begin{gathered}
\left.\left[\left\{\left(\eta^{5}-\mathrm{Pdl} l^{\prime}\right) \mathrm{Mn}\left(\eta^{5}-\mathrm{C}_{5} \mathrm{H}_{5}\right)\right]\right\}_{2} \mathrm{Mn}\right] \\
(\mathbf{5}, \mathrm{S}=1 / 2) \\
\left.\left[\left\{\left(\eta^{5}-\mathrm{Pdl} l^{\prime}\right) \mathrm{Mn}\left(\eta^{5}-\mathrm{C}_{5} \mathrm{H}_{5}\right)\right]\right\}_{2} \mathrm{Mn}\right] \\
(\mathbf{5}, \mathrm{S}=5 / 2) \\
\left.\left[\left\{\left(\eta^{5}-\mathrm{Pdl} l^{\prime}\right) \mathrm{Mn}\left(\eta^{5}-\mathrm{C}_{5} \mathrm{H}_{5}\right)\right]\right\}_{2} \mathrm{Mn}\right] \\
(\mathbf{5}, \mathrm{S}=9 / 2) \\
\left.\left.\left[\left\{\left(\eta^{5}-\mathrm{Pdl}\right)^{\prime}\right) \mathrm{Mn}\left(\eta^{5}-\mathrm{C}_{5} \mathrm{H}_{5}\right)\right]\right\}_{2} \mathrm{Mn}\right] \\
(\mathbf{5}, \mathrm{S}=111 / 2) \\
\left.\left[\left\{\left(\eta^{5}-\mathrm{Pdl} l^{\prime}\right) \mathrm{Mn}\left(\eta^{5}-\mathrm{C}_{5} \mathrm{H}_{5}\right)\right]\right\}_{2} \mathrm{Mn}\right] \\
(\mathbf{5}, \mathrm{S}=15 / 2)
\end{gathered}
$$

\begin{tabular}{|c|c|c|c|}
\hline$\left[\left(\eta^{5}-\mathrm{Cp}^{\prime \prime}\right) \mathrm{Mn}\left(\mathrm{Pdl}{ }^{\prime}\right)\right](2, \mathrm{~S}=1 / 2)$ & -2324.644151 & -2324.607305 & -2324.704902 \\
\hline$\left[\left(\eta^{5}-\mathrm{Cp} "\right) \mathrm{Mn}\left(\mathrm{Pdl}^{\prime}\right)\right](2, \mathrm{~S}=5 / 2)$ & -2324.648385 & -2324.608895 & -2324.715495 \\
\hline$\left[\left(\eta^{5}-C p^{\prime \prime}\right) \operatorname{Mn}\left(\eta^{5}-C p^{\prime}\right)\right](3, S=1 / 2)$ & -2323.494434 & -2323.456788 & -2323.556396 \\
\hline$\left[\left(\eta^{5}-\mathrm{Cp} "\right) \mathrm{Mn}\left(\eta^{5}-\mathrm{Cp} \mathrm{p}^{\prime}\right)\right](\mathbf{3}, \mathrm{S}=5 / 2)$ & -2323.485824 & -2323.446274 & -2323.553334 \\
\hline$\left[\left(\mathrm{Pdl}^{\prime}\right)_{2} \mathrm{Mn}\right](\mathbf{4}, \mathrm{S}=1 / 2)$ & -2168.725567 & -2168.691896 & -2168.782616 \\
\hline$\left[\left(\mathrm{Pdl}{ }^{\prime}\right)_{2} \mathrm{Mn}\right](4, \mathrm{~S}=3 / 2)$ & -2168.726073 & -2168.690928 & -2168.787540 \\
\hline$\left[\left(\mathrm{Pdl}{ }^{\prime}\right)_{2} \mathrm{Mn}\right](\mathbf{4}, \mathrm{S}=5 / 2)$ & -2168.727178 & -2168.693346 & -2168.788500 \\
\hline
\end{tabular}

$\begin{array}{lll}-4857.951650 & -4857.905922 & -4858.026091 \\ -4858.034736 & -4857.988934 & -4858.111206 \\ -4857.964310 & -4857.913418 & -4858.056747 \\ -4857.988864 & -4857.939620 & -4858.071215 \\ -4857.964499 & -4857.913475 & -4858.056391\end{array}$

B97D:

${ }^{a}$ DFT energy incl. ZPE.

${ }^{b}$ standard conditions $T=298.15 \mathrm{~K}$ and $p=1 \mathrm{~atm}$.

\section{2 (Biorthogonalized) Kohn Sham orbitals for compounds 2-5}

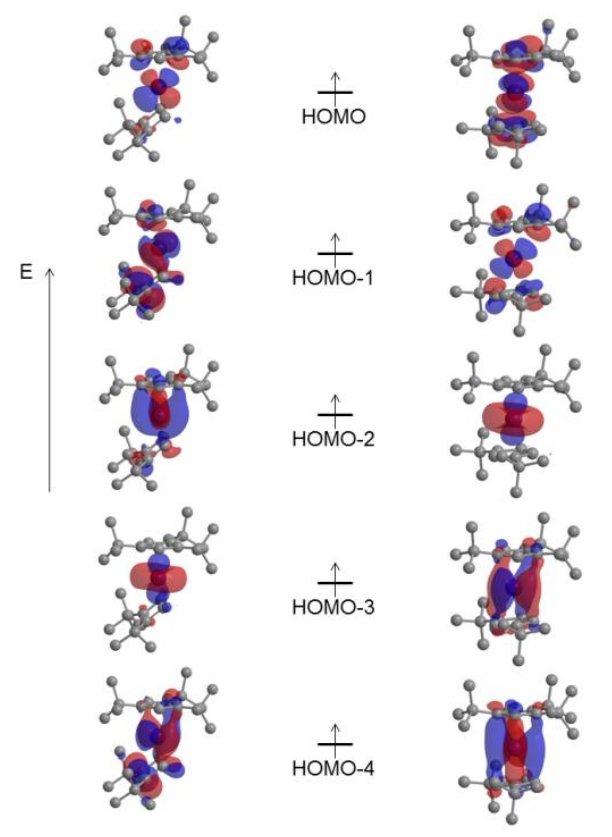

Figure S9. (Biorthogonalized) Kohn Sham orbitals for complexes $\mathbf{2}$ and $\mathbf{3}$ (isocontour value $=0.025$ ). 


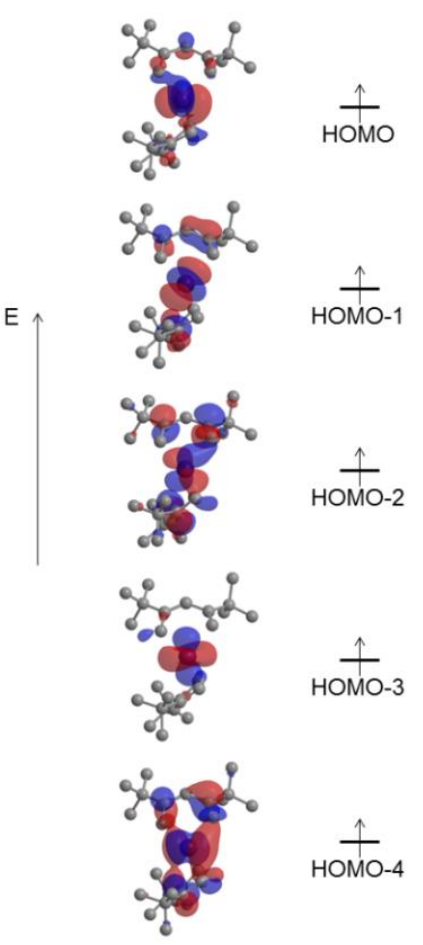

Figure S10. (Biorthogonalized) Kohn Sham orbitals for complex 4 (isocontour value $=0.025$ ).

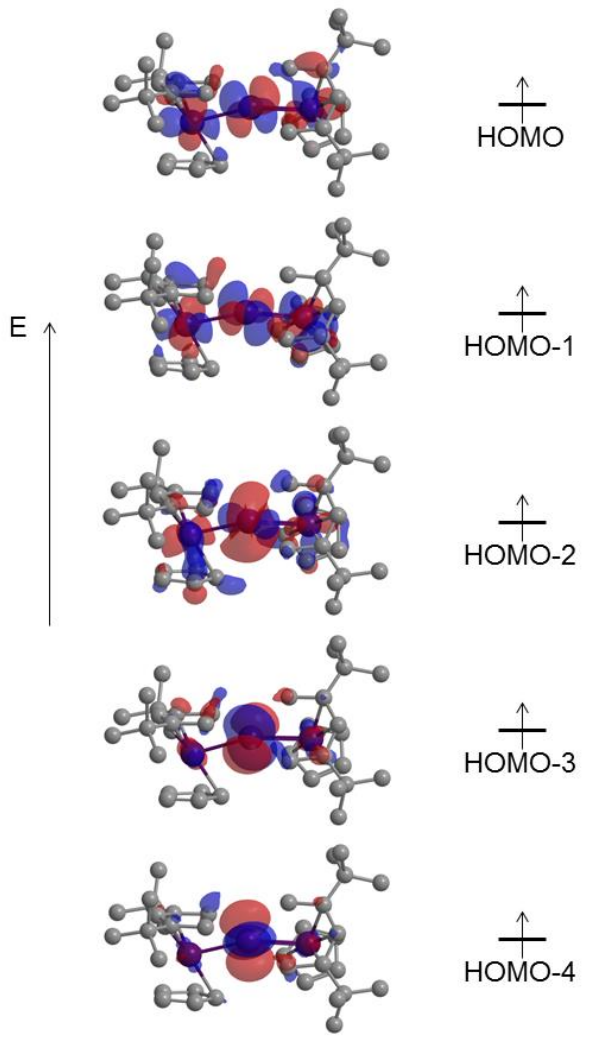

Figure S11. (Biorthogonalized) Kohn Sham orbitals for complex 5 (isocontour value $=0.025$ ). 


\subsection{Computed molecular structures and spin states for complex 5}
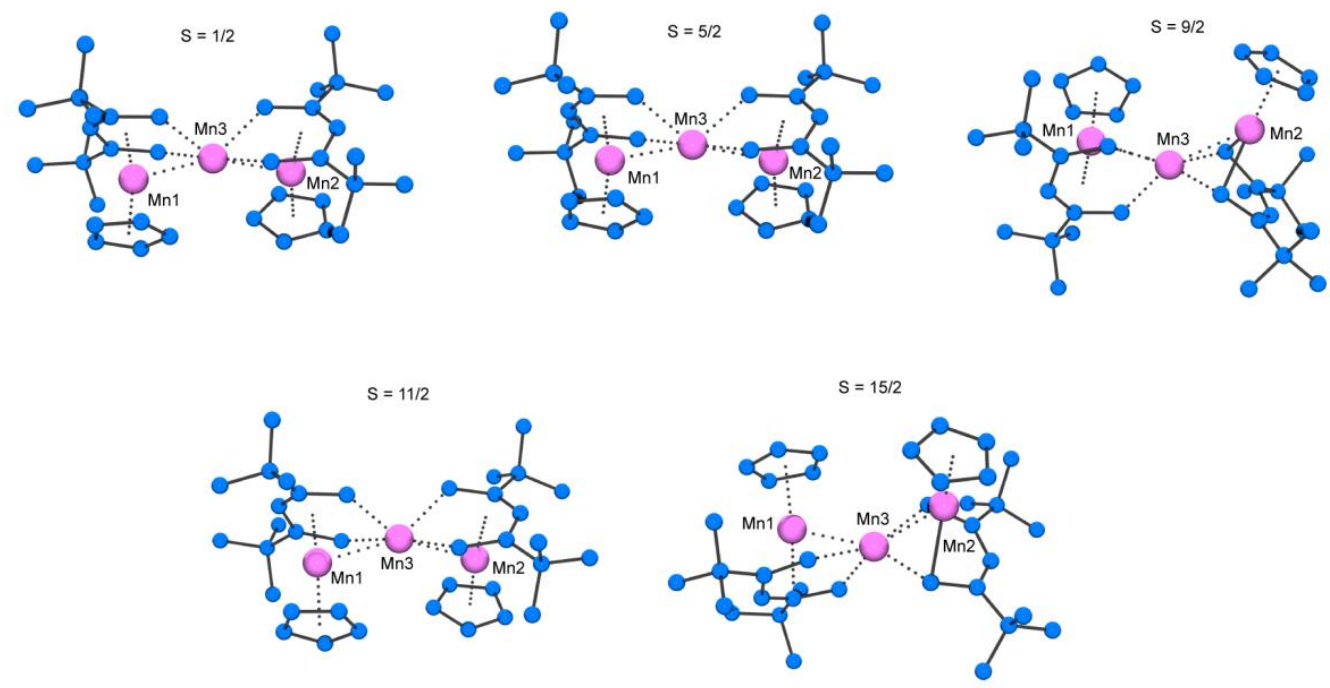

Figure S10. Computed molecular structures for complex 5 assuming different spin states (B3LYP/6-311G**).

Table S4. Selected bond distances $(\AA)$ and angles $\left(^{\circ}\right)$ for computed molecular structures of 5

\begin{tabular}{c|cccccc} 
& $\mathrm{S}=1 / 2$ & $\mathrm{~S}=5 / 2$ & $\mathrm{~S}=9 / 2$ & $\mathrm{~S}=11 / 2$ & $\mathrm{~S}=15 / 2$ & exp. \\
\hline Pdl'1(cent)-Mn1 & 1.519 & 1.519 & 1.783 & 1.758 & 2.120 & $\mathbf{1 . 5 0 8 2 ( 1 1 )}$ \\
Cp1(cent)-Mn1 & 1.786 & 1.786 & 2.120 & 2.145 & 1.782 & $\mathbf{1 . 7 4 9 0 ( 1 5 )}$ \\
Pdl'2(cent)-Mn2 & 1.526 & 1.519 & - & 1.633 & - & $\mathbf{1 . 5 1 2 3 ( 1 2 )}$ \\
Cp2(cent)-Mn1 & 1.784 & 1.786 & 2.091 & 1.944 & 2.089 & $\mathbf{1 . 7 4 6 5 ( 1 1 )}$ \\
Mn1-Mn3 & 2.486 & 2.524 & 2.753 & 2.730 & 2.746 & $\mathbf{2 . 5 0 0 7 ( 4 )}$ \\
Mn2-Mn3 & 2.456 & 2.524 & 2.763 & 2.511 & 1.762 & $\mathbf{2 . 5 0 9 1 ( 4 )}$ \\
Mn1-Mn3-Mn2 & 155.98 & 158.43 & 141.30 & 149.17 & 140.84 & $\mathbf{1 5 9 . 8 9 1 ( 1 7 )}$ \\
\hline
\end{tabular}

\subsection{Spin distribution and NBO charges for complex 5}

Table S5. Spin distribution and NBO charges for complex $5(S=5 / 2)$

\begin{tabular}{|c|c|c|c|c|}
\hline & $\begin{array}{l}\text { Natural Electron } \\
\text { Configuration }\end{array}$ & Natural charge & $\begin{array}{l}\text { Mulliken } \\
\text { charges }\end{array}$ & $\begin{array}{l}\text { Mulliken spin } \\
\text { density }\end{array}$ \\
\hline \multirow[t]{2}{*}{ Mn1 } & [core] 4s (0.21) 3d (6.09) & 0.67308 & 0.8924 & 0.2482 \\
\hline & $4 \mathrm{p}(0.03) 5 \mathrm{~s}(0.01) 4 \mathrm{~d}(0.01)$ & & & \\
\hline \multirow[t]{2}{*}{$\mathrm{Mn} 2$} & [core] 4s $(0.21) \mathbf{3 d}(\mathbf{6 . 0 9})$ & 0.67319 & 0.8924 & 0.2483 \\
\hline & $4 \mathrm{p}(0.03) 5 \mathrm{~s}(0.01) 4 \mathrm{~d}(0.01)$ & & & \\
\hline \multirow[t]{2}{*}{ Mn3 } & [core] 4s $(0.28) \mathbf{3 d}(\mathbf{5 . 2 1})$ & 1.50213 & 1.2200 & 4.6638 \\
\hline & $4 p(0.02) 5 s(0.01)$ & & & \\
\hline
\end{tabular}




\section{References}

[1] P. Coppens, Nature (London), 1964, 204, 1298.

[2] W. Bünder and E. Weiss, Z. Naturforsch., Teil B, 1978, 33, 1235.

[3] Gaussian 09, Revision A.1, M. J. Frisch, G. W. Trucks, H. B. Schlegel, G. E. Scuseria, M. A. Robb, J. R. Cheeseman, G. Scalmani, V. Barone, B. Mennucci, G. A. Petersson, H. Nakatsuji, M. Caricato, X. Li, H. P. Hratchian, A. F. Izmaylov, J. Bloino, G. Zheng, J. L. Sonnenberg, M. Hada, M. Ehara, K. Toyota, R. Fukuda, J. Hasegawa, M. Ishida, T. Nakajima, Y. Honda, O. Kitao, H. Nakai, T. Vreven, J. A. Montgomery, Jr., J. E. Peralta, F. Ogliaro, M. Bearpark, J. J. Heyd, E. Brothers, K. N. Kudin, V. N. Staroverov, R. Kobayashi, J. Normand, K. Raghavachari, A. Rendell, J. C. Burant, S. S. Iyengar, J. Tomasi, M. Cossi, N. Rega, J. M. Millam, M. Klene, J. E. Knox, J. B. Cross, V. Bakken, C. Adamo, J. Jaramillo, R. Gomperts, R. E. Stratmann, O. Yazyev, A. J. Austin, R. Cammi, C. Pomelli, J. W. Ochterski, R. L. Martin, K. Morokuma, V. G. Zakrzewski, G. A. Voth, P. Salvador, J. J. Dannenberg, S. Dapprich, A. D. Daniels, Ö. Farkas, J. B. Foresman, J. V. Ortiz, J. Cioslowski, and D. J. Fox, Gaussian, Inc., Wallingford CT, 2009.

[4] X. Cao and M. Dolg, J. Chem. Phys. 2001, 115, 7348. 